\title{
Assessment of the embodied carbon in precast concrete wall panels using a hybrid life cycle assessment approach in Malaysia
}

\author{
Wan Mohd Sabki Wan Omar, Jeung-Hwan Doh*, Kriengsak Panuwatwanich, Dane Miller \\ Griffith School of Engineering, Griffith University, Gold Coast Campus, Queensland 4222, Australia
}

\section{A R T I C L E I N F O}

\section{Keywords:}

Life-cycle

Embodied energy

Carbon

Malaysia

\begin{abstract}
A B S T R A C T
There is currently growing interest in quantifying the direct and indirect carbon emissions embodied in construction materials and their components production. Previous research shows that indirect emission could be higher than direct emission for energy intensity materials such as cement and steel reinforcement. Quantifying direct emissions alone would underestimate the carbon emissions associated with a material and in turn its environmental impact. The assessment of indirect emissions is a challenging task involving upstream processes of material production. This paper investigates the existing literature on the quantification of embodied carbon by both direct and indirect emissions as well as demonstrating the application of a hybrid life cycle assessment method in building construction. The focus of this paper is the Malaysian context however the principles apply universally. A typical 2-storey residential building has been investigated to determine the total carbon emissions when comparing two construction techniques: conventionally reinforced concrete and precast concrete panels. This paper demonstrates the application of hybrid life cycle assessment by expanding the boundaries of process methods and reducing the sensitivities of $\mathrm{I}-\mathrm{O}$ life cycle assessment to the raw material price fluctuation for product manufacturing.
\end{abstract}

(C) 2013 Published by Elsevier B.V.

\section{Introduction}

The selection of appropriate construction materials and technologies is vital in satisfying user requirements. Material selection can also contribute to projects social outcomes without compromising adverse environmental impacts. New construction technologies and methodologies, including precast concrete wall panels, have emerged as an alternative to conventional in situ concrete construction. This and many other alternatives have increased the awareness of industry and academics to critically consider the environmental aspect during selection of an appropriate building design. Many scholars have highlighted that accurate estimation of environmental impact is part of a challenging task being attempted by many researchers. In recent years, attempts are increasing for the design of sustainable concrete structures. One of key indicators for climate change and the environmental impacts associated with construction are greenhouse gas (GHG) emissions. It is well known that cement, steel reinforcement and concrete are common material inputs used in both conventionally reinforced and precast concrete panel production. Hence, assessment

\footnotetext{
* Corresponding author. Tel.: +61 7 55529141; fax: +61 755528065.

E-mail addresses: J.doh@griffith.edu.au, engdoh@gmail.com (J.-H. Doh).
}

of embodied carbon in these construction materials can give a significant influence to the environmental impact assessment of these structures.

Assessment of carbon emissions involves both direct and indirect emissions. Direct emissions normally originate from energy consumption during on-site and off-site activities such as construction, prefabrication, transportation and administration. Indirect emissions involve energy consumption from fossil fuels during production and manufacturing of building materials in the main process, as well as upstream and downstream processes (Dixit, Fernández-Solís, Lavy, \& Culp, 2010). Direct emissions account for $23 \%$ of total carbon emissions in the building sector, whereas indirect domestic and imported emissions account for $46 \%$ and $31 \%$ of total carbon emission respectively (Nässén, Holmberg, Wadeskog, \& Nyman, 2007). Construction materials with high emission intensities like cement and steel reinforcement could have indirect emissions greater than $50 \%$. For this reason, quantifying direct emission alone would provide an unreliable result and misleading interpretation in terms of LCA.

There are presently many attempts at compiling reliable systems for the quantification of carbon emissions in construction materials and products. There has also previously been numerous studies conducted regarding embodied carbon assessment, however, there is a requirement for more studies to address the significant indirect emissions that influence the accuracy of any 
assessment (Dixit, Fernández-Solís, Lavy, \& Culp, 2012). In response to this, studies have been conducted to quantify both direct and indirect carbon emissions. For instance, a comprehensive framework of the life cycle energy of building construction assemblies has been proposed by Crawford, Czerniakowski, and Fuller (2010) to rank the assemblies according to their performance. On the other hand, a study of the life cycle GHG emission and energy analysis of prefabricated reusable building modules has been conducted by Aye, Ngo, Crawford, Gammampila, and Mendis (2012) and found that a steel-framed prefabricated system resulted in reduced material consumption of up to $78 \%$ compared to conventional concrete construction. Similarly, further highlighting the benefits of prefabricated building systems, a study by Monahan and Powell (2011), assessed the embodied energy and emission of a construction low energy building using modern method of construction (MMC) known as a prefabricated panelized timber framed system. This system when compared with more traditional methods of construction resulted in a $34 \%$ reduction in embodied carbon. Peng and Pheng (2011) conducted research studies to quantify the carbon emissions of precast concrete columns but failed to address the influence of indirect emissions, subsequently underestimating the results for the LCA. None of these studies, however, estimate the carbon emissions embodied in precast concrete wall panels or address the significant amount of indirect emissions in their manufacturing and productions processes. This research aims to quantify carbon emissions of construction materials and precast concrete products by considering both direct and indirect emission using a Hybrid LCA method (HLCA). The HLCA is proposed in order to evaluate both environmental and economic aspects of carbon emissions by estimating carbon-added and valued-added outcomes at each stage of the precast product manufacturing supply chain.

\section{Methodology}

LCA is defined as: "a technique for assessing the environmental aspects and potential impacts associated with a product, by: (1) compiling an inventory of relevant inputs and outputs of a product system; (2) evaluating the potential environmental impacts; and (3) interpreting the results of the inventory analysis and impact assessment phases" (ISO 14040, 2006). It outlines four phases to be performed which encompass: (1) goal and scope definition; (2) inventory analysis; (3) impact assessment; and (4) interpretation. Based on the different system scopes and theory, LCA can be classified as process LCA, input-output LCA and hybrid LCA.

\subsection{Process LCA (PLCA)}

Process LCA is most preferred for the particular processes, products or manufacturing chains for which the physical flow of goods and services can be easily identified and traced (Bullard, Penner, \& Pilati, 1978). It is a time and labour intensive process as there are numerous, often difficult to identify energy inputs required for product manufacturing (Lenzen \& Treloar, 2002). Nässén et al. (2007) found that process LCA induces systematic truncation errors due to the incomplete definition of system boundary. Almost $90 \%$ of specific energy consumption was from top-down analysis due to the truncation error defined during bottom-up approach. Furthermore, the bottom-up approach underestimated the energy consumption for transportation, services, etc. during the production phase compared to the use phase (Nässén et al., 2007). The main reason is that the use phase is easily estimated by direct energy consumption.

\subsection{Input-output LCA (I-O LCA)}

The I-O LCA is calculated based on the flow of materials in an economy structure in order to determine the amount of primary energy required to produce a specific product or service. The I-O LCA uses the economic I-O tables of a national economic structure. It uses a top-down linear macroeconomic approach to describe the complex inter-industry relationship in terms of monetary transactions in industrial structure (Lenzen, Murray, Korte, \& Dey, 2003). Furthermore, it is the best suited to systematically estimate the indirect effect of carbon emissions and improve the method of assessment in a LCA framework (Williams, Weber, \& Hawkins, 2009). According to Crawford (2008), the use of I-O data improves the reliability of LCA by increasing completeness and reliability of life cycle inventories compared to the traditional inventory analysis. The capital inputs were accounted for $22 \%$ of total input to a specific products I-O table (Crawford, 2008). An I-O table maps the flow of goods and services between sectors in an economic structure (Treloar, 1997). The flow of energy within an economic structure is possible to trace by assessing the input and output of monetary flows from the energy producing sectors and converting it to a physical energy value (Alcorn \& Baird, 1996). By using I-O LCA, all energy transactions within national economic structures are identified and captured. These can then be used to assess inputs and outputs of energy.

In spite of its advantages, I-O LCA has several limitations and using I-O LCA to replace process LCA does not always ensure the accuracy of the model being studied. Some of the potential errors that limit the I-O methodology are (1) the proportionality and homogeneity function, (2) handling of imports, (3) total error, (4) product aggregation in sectors, (5) conversion of economical data into physical data and (6) double counting in energy supply sectors (Acquaye, 2010; Nässén et al., 2007; Treloar, Love, \& Faniran, 2001).

\subsection{Hybrid LCA (HLCA)}

The principal aim of HLCA is to combine the advantages of the more accurate process LCA and the extended system boundary of the I-O LCA (Mattila, Pakarinen, \& Sokka, 2010). It combines balance among system boundary, specialization of model applicability as well as time and cost efficiency. With HLCA, both upstream and downstream processes of manufacturing products can be extended by considering both direct and indirect emissions. Furthermore, HLCA can deal with cut off error, aggregation, temporal and geographic uncertainty (Williams et al., 2009). In dealing with cut off error, HLCA becomes a supplement tool of excluded processes in process LCA. It offers solutions for using more detailed process LCA data in I-O LCA framework to minimize aggregation uncertainty. Moreover, HLCA can assists in estimating the scale of temporary uncertainty. Detailed I-O LCA is typically issued every five years. Therefore, gathering price from a particular period of time enables quick scoping analysis of temporal variability. Finally, HLCA can enhance the estimation and management of geographic uncertainty (Williams et al., 2009). Despite its advantages, HLCA is known for its data and time intensive requirements.

\subsection{System boundary of research}

The system boundary needs to be clearly defined to ensure reliability and consistency of data and results. The first step is defining the boundary of construction materials and products by using HLCA. This ensures that inter-industry supply chain relationships can be identified. More specifically, the construction materials consist of cement, aggregate, water, steel reinforcement and concrete that contributes to both direct and indirect carbon emissions embodied in precast concrete wall panel production. These can 


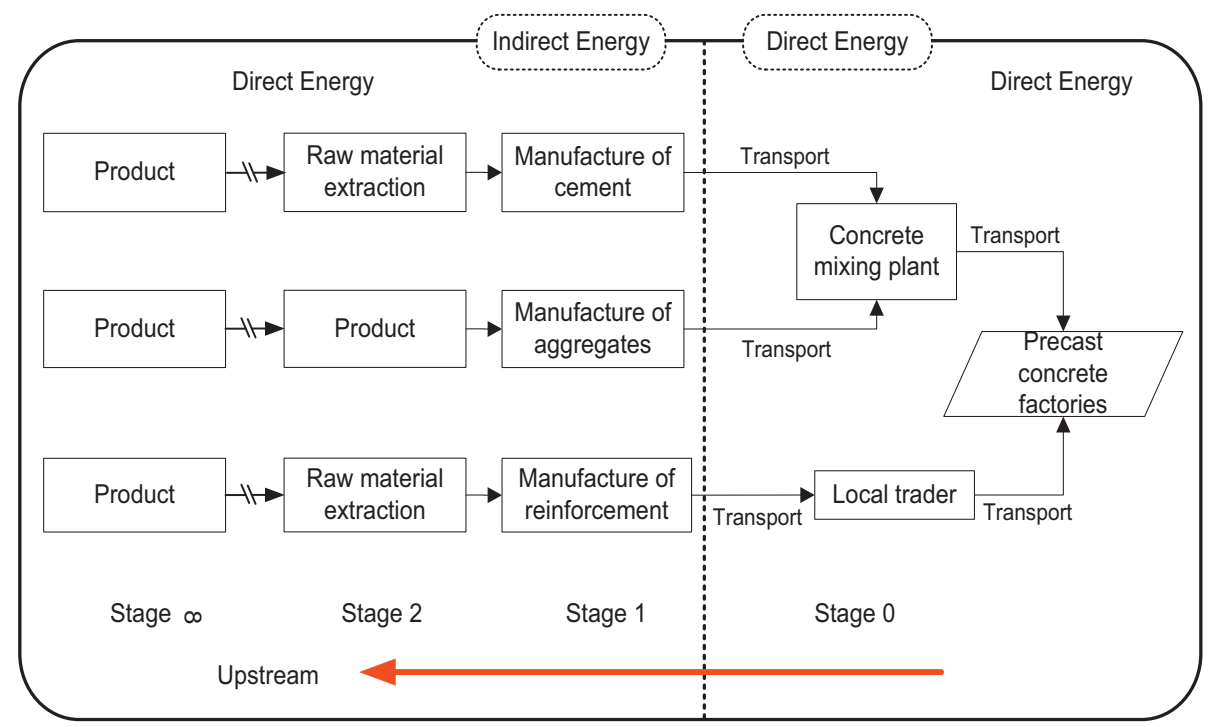

Fig. 1. System boundary for precast concrete products.

all be traced accordingly. Nässén et al. (2007) reported that the upstream processes involve indirect domestic and imported emissions accounting for $46 \%$ and $31 \%$ of total carbon emissions, respectively. The detailed system boundary for the material input required to produce precast concrete products is depicted in Fig. 1.

The second step is identifying system boundary by using partial LCA, from cradle to site of building construction. The detailed system boundary is given in Fig. 2. Among the life cycle phases, carbon emissions from the use and demolition phase were excluded. The system boundary of this research includes extraction of raw materials, transportation and manufacturing of construction materials and products up to construction site. The recurring carbon emissions, which cover renovation and refurbishment of construction products, are beyond the scope of this research. This is due mainly to the many assumptions required to include the entire life of a building. Therefore the building is assumed to require no replacement precast concrete products during its entire service life.

\subsection{Selection of life cycle inventory (LCI) and data sources}

Life cycle inventory ( $\mathrm{LCI}$ ) analysis refers to the collection of data and calculation procedures to estimate relevant inputs and outputs of a product system. This is a vital role in providing basis data for this research (ISO 14040, 2006). LCI is an iterative process depending on the completeness of data. Incomplete data could result in revising the goal and scope of the research. It also involves refining and

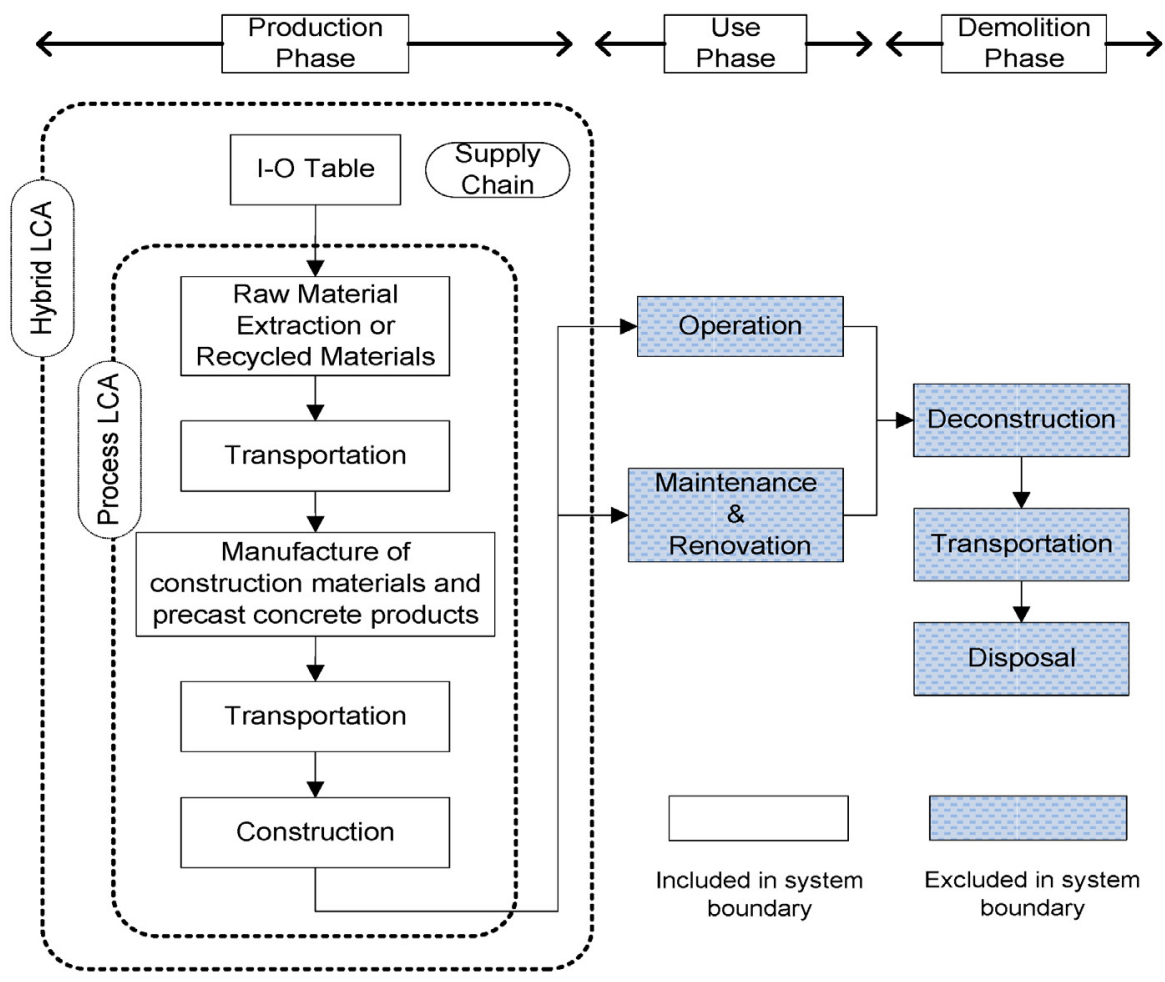

Fig. 2. System boundary for partial LCA in building construction process. 
Table 1

Data sources for energy input and carbon emission intensity.

\begin{tabular}{|c|c|}
\hline Embodied carbon and energy consumption of materials and components & References \\
\hline Design of concrete mix & BS 1881: Part 125: 1986 \\
\hline Carbon emission of construction materials & $\begin{array}{l}\text { Hammond and Jones (2011), local and national inventory } \\
\text { databases }\end{array}$ \\
\hline Carbon emission from transportation & $\begin{array}{l}\text { Goggins et al. (2010), Department of Climate Change and } \\
\text { Energy Efficiency (2011) }\end{array}$ \\
\hline Energy input from precast production factory & Marceau et al. (2007) \\
\hline Carbon emission factor of electricity generation & $\begin{array}{l}\text { International Energy Agency (2005), Malaysia Energy } \\
\text { Centre (2008) and Malaysia Energy Commission (2005) }\end{array}$ \\
\hline
\end{tabular}

redefining the system boundary that leads to changing the goal and scope of research. Data collection is time consuming and resourceintensive involving various sources of data (Finnveden et al., 2009).

For the purpose of this research, the building structural systems commonly used in the Malaysian construction industry are classified into conventional and industrialized building system (IBS) (Abdul Kadir, Lee, Jaafar, Sapuan, \& Ali, 2006). The conventional system includes column, beam and slabs forming the framed structure and burnt clay bricks as functional walls. The rest are different alternative building system classified according to IBS structural system which includes precast wall panels, hollow block and precast column and beam frame. The precast concrete wall panel commonly used in Malaysia was selected to be compared with the conventional structural system as described above.

The selection of data sources is vital to ensure reliability and consistency of research. The selection of data sources is obtained from previous LCI research studies. The references of data sources are given in Table 1.

\section{HLCA model development}

\subsection{Derivation of carbon emission intensity}

The I-O LCA is based on the most recently published data of the Malaysian economic structure, namely I-O tables for the year 2005 (Department of Statistics, 2010). It provides indirect emission intensities for a particular product sector being studied. The direct emission intensity of the cement, aggregate, steel reinforcement and concrete were obtained from the PLCA. The detailed flows of the derivation processes are illustrated in Fig. 3.

\subsection{Process LCA for direct carbon emission intensity}

Carbon emissions are obtained from PLCA to identify direct emission contributions from precast concrete plant operations and transportation. These are presented in Table 2. In order to estimate direct emission contributions, carbon emissions for construction materials using PLCA are obtained from available local or international databases. The most current database for carbon emission is the Inventory of Carbon and Energy database (ICE) developed by the University of Bath, UK (Hammond \& Jones, 2011). Since, this research scope focuses on the Malaysian context, local information on the manufacture of building materials should be identified. Although Malaysia's specific data is preferable, it is noted that the current inventory of local carbon emissions is insufficient and incomplete. On this basis the latest ICE database was adopted.

Carbon emissions during transportation involve the transportation of concrete, steel reinforcement and precast concrete products to site. The majority of precast concrete factories in Malaysia have their own concrete production plant due to the transportation costs and quality control requirements of concrete production. Therefore, the transportation distance only involves delivery of steel reinforcement and the final precast products. These are assumed to be $300 \mathrm{~km}$ and $30 \mathrm{~km}$, respectively. For the conventional in situ con-

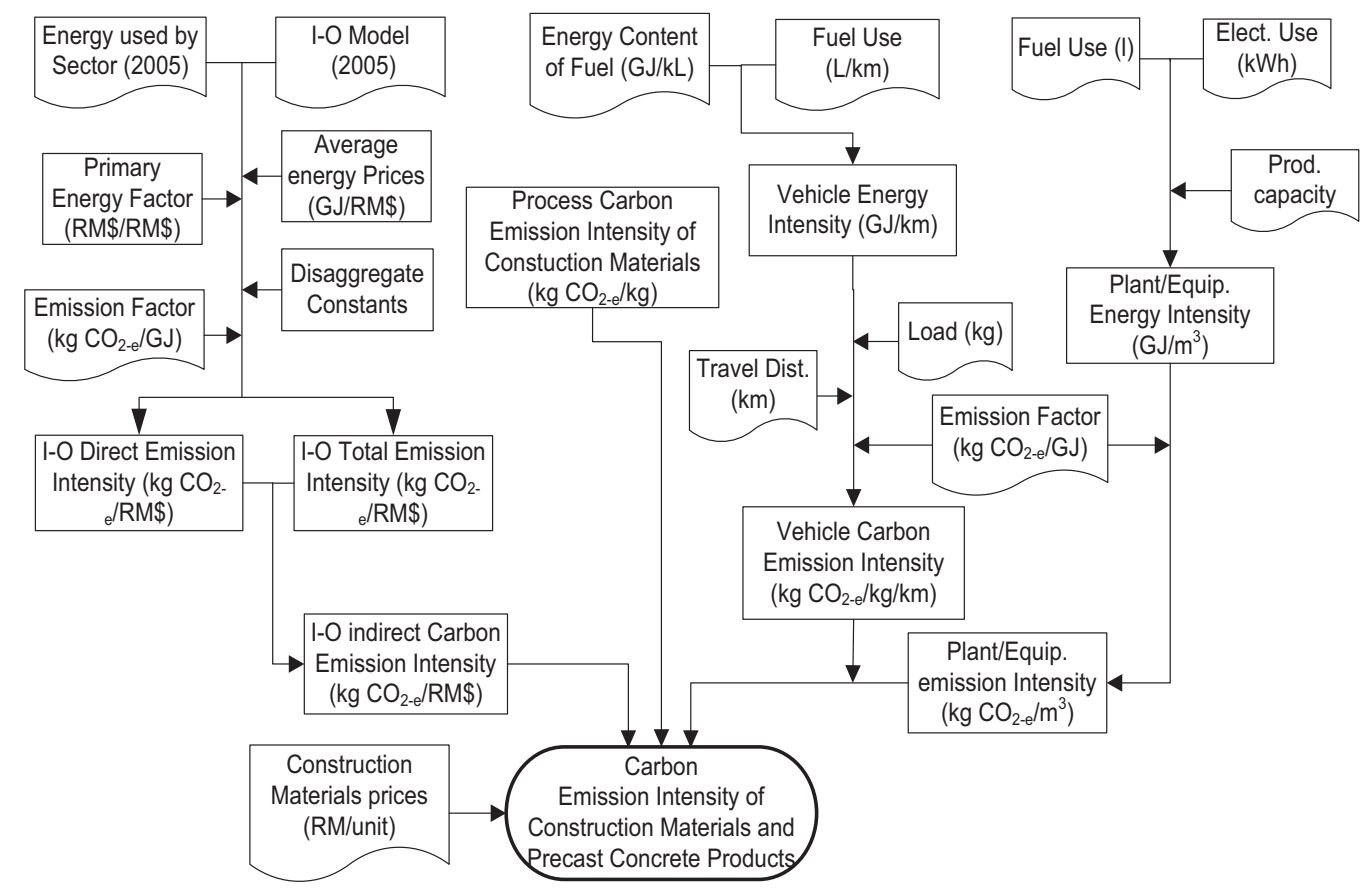

Fig. 3. Flowchart of carbon emission of building materials and precast concrete products. 
Table 2

Energy input and carbon emission for transportation and plant operation.

\begin{tabular}{|c|c|c|}
\hline Description & Energy intensity & Emission factor ${ }^{\mathrm{C}}$ \\
\hline \multicolumn{3}{|c|}{ Precast concrete plant operation ${ }^{\text {a }}$} \\
\hline Diesel fuel & $191 \mathrm{MJ} / \mathrm{m}^{3}$ & $13.275 \mathrm{~kg} \mathrm{CO} 2_{-e} / \mathrm{m}^{3}$ \\
\hline Natural gas & $42 \mathrm{MJ} / \mathrm{m}^{3}$ & $2.156 \mathrm{~kg} \mathrm{CO}{ }_{2-e} / \mathrm{m}^{3}$ \\
\hline Electricity & $14 \mathrm{MJ} / \mathrm{m}^{3}$ & $3.028 \mathrm{~kg} \mathrm{CO} \mathrm{CO}_{2-e} / \mathrm{m}^{3}$ \\
\hline Total & $247 \mathrm{MJ} / \mathrm{m}^{3}$ & $18.459 \mathrm{~kg} \mathrm{CO} 2-e / \mathrm{m}^{3}$ \\
\hline \multicolumn{3}{|c|}{ Transportation (concrete) ${ }^{\mathrm{b}}$} \\
\hline Outbound & $1.903 \mathrm{MJ} / \mathrm{m}^{3} / \mathrm{km}$ & $0.133 \mathrm{~kg} \mathrm{CO}{ }_{2-e} / \mathrm{m}^{3} / \mathrm{km}$ \\
\hline Return & $1.404 \mathrm{MJ} / \mathrm{m}^{3} / \mathrm{km}$ & $0.098 \mathrm{~kg} \mathrm{CO}{ }_{2-e} / \mathrm{m}^{3} / \mathrm{km}$ \\
\hline \multicolumn{3}{|c|}{ Transportation (reinforced steel) ${ }^{\mathrm{b}}$} \\
\hline Outbound & $4.6 \times 10^{-4} \mathrm{MJ} / \mathrm{kg} / \mathrm{km}$ & $3.21 \times 10^{-5} \mathrm{~kg} \mathrm{CO}{ }_{2-e} / \mathrm{kg} / \mathrm{km}$ \\
\hline Return & $3.5 \times 10^{-4} \mathrm{MJ} / \mathrm{kg} / \mathrm{km}$ & $2.44 \times 10^{-5} \mathrm{~kg} \mathrm{CO}{ }_{2-e} / \mathrm{kg} / \mathrm{km}$ \\
\hline \multicolumn{3}{|c|}{ Transportation (precast products) } \\
\hline Outbound & $1.903 \mathrm{MJ} / \mathrm{m}^{3} / \mathrm{km}$ & $0.133 \mathrm{~kg} \mathrm{CO}{ }_{2-e} / \mathrm{m}^{3} / \mathrm{km}$ \\
\hline Return & $1.404 \mathrm{MJ} / \mathrm{m}^{3} / \mathrm{km}$ & $0.098 \mathrm{~kg} \mathrm{CO} 2_{2-e} / \mathrm{m}^{3} / \mathrm{km}$ \\
\hline \multicolumn{3}{|c|}{ a Marceau et al. (2007). } \\
\hline \multicolumn{3}{|c|}{ b Goggins et al. (2010). } \\
\hline c Departme & mate $\mathrm{Ch}$ & ссу (2011). \\
\hline
\end{tabular}

crete system, the transportation distance was assumed to be $30 \mathrm{~km}$ from concrete mix plant to site and $300 \mathrm{~km}$ from steel manufacturer to the site. The carbon emitted during transportation for concrete and precast concrete wall panels are assumed to be similar. Due to the weight discrepancy, emissions on outbound and inbound journeys were $1.903 \mathrm{MJ} / \mathrm{m}^{3} / \mathrm{km}$ and $1.404 \mathrm{MJ} / \mathrm{m}^{3} / \mathrm{km}$, respectively. These were similar to the emissions estimated by Goggins, Keane, and Kelly (2010).

The energy input from precast concrete production and plant operation involved fossil fuel and electricity consumption. The energy used by the precast concrete plant is obtained from operational energy estimated from US and Canadian precast concrete plants and can be considered in this study (Marceau, Nisbet, \& VanGeem, 2007). However, energy contributions for the production of precast concrete are known to be less significant and were estimated to be less than $0.6 \%(6.5 \mathrm{kWh})$ of total emissions during precast concrete production (Peng \& Pheng, 2011). It suggests that at least $95 \%$ of total anticipated emission are included in this assessment (PAS 2050 2011).

\subsection{I-O LCA for indirect carbon emission intensity}

Indirect carbon emissions are not directly related to on-site construction but rather the upstream process of construction material production. These also include the construction procurement supply chain (energy used to manufacture building materials, excavation of raw aggregate, design, cement production, design team activities, etc.). The initial stage for deriving indirect emissions are obtained from the Malaysian national economic structure embedded in the I-O tables. The most recent Malaysian I-O tables published by the Malaysian Department of Statistics in 2005 were selected in I-O LCA. These are publicly issued every five years.

The Malaysian economy structure in the 2005 Input-Output tables is divided into 120 by 120 different commodity sectors. The direct energy intensity for the four aggregated energy supply sectors being: crude oil and natural gas (11100 and 11200), other mining and quarrying (10100), petroleum refinery (23100), and electricity and gas (40100 and 40200) are calculated across 120 output columns which represent different commodity sectors of the Malaysian economy (Department of Statistics, 2010). The Malaysian Department of Statistics provides a matrix of domestic production and imports, commodity by commodity in the 2005 I-O table. Acquaye and Duffy (2010) demonstrated that $41.6 \%$ of emissions rose from imported products. Therefore, both the matrix of domestic production and import commodities are combined to better represent the technological input structure of industries and the product composition of final demand.

The reliability and consistency of carbon emission assessments depend on the consideration of primary energy instead of delivered energy (Dixit et al., 2010). The primary energy is defined as energy consumed from direct point sources (coal, natural gas or crude oil) embodied in fossil fuel consumed by the purchaser (electricity producer) (Dixit et al., 2012). Neglecting losses due to plant fuel usage, transmission and distribution in delivered energy leads to misleading and ambiguous interpretations of final results. Therefore, the Malaysian average energy tariffs and primary energy factors were derived to convert delivered energy to primary energy as shown in Table 3.

According to Mongelli, Suh, and Huppes (2005), aggregation of many different products into one sector in the national I-O table reduces its applicability to a specific product or product sector. Acquaye, Duffy, and Basu (2011) used a disaggregation constant to reduce aggregation problems in direct emission intensity estimation. For instance, in the Malaysia I-O table, some energy supplies are aggregated together with other energy supply sectors (for instance 'crude oil and natural gas' sector is an aggregation of two energy supply sectors: crude oil and natural gas and the 'electricity and gas' sector is an aggregation of electricity and gas supply or utilities sectors). Therefore, disaggregation analysis is conducted as proposed by Acquaye et al. (2011) by estimating disaggregation constants from the Malaysian energy balance and the Malaysian 2005 I-O tables. The aggregated energy supply sector is split into individual energy sources as shown in Table 3. The use of the disaggregation constant has advantages in the estimation of direct emission intensity. Among these advantages are:

- It enables specific energy factors and energy tariffs to be used instead of average values for an aggregated energy supply sector; and

- The use of a disaggregation constant helps to avoid double counting of energy supply sectors.

The primary emission factor is multiplied to estimate the direct emission intensity of each basic material input required for precast

Table 3

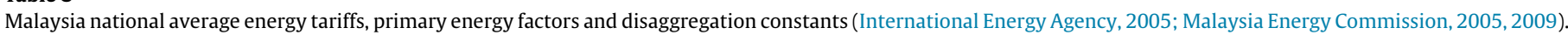

\begin{tabular}{|c|c|c|c|c|}
\hline MSIC2000 & Energy supply sector & $\begin{array}{l}\text { Malaysia average } \\
\text { energy tariffs, } T_{e} \\
(\mathrm{GJ} / \mathrm{RM} \$)\end{array}$ & Primary energy factor (PEF) & $\begin{array}{l}\text { Disaggregation } \\
\text { constant, } C_{d}\end{array}$ \\
\hline 11100 & Crude oil & 0.0356 & 1.00 & 0.61 \\
\hline 11200 & Natural gas & 0.0608 & 1.62 & 0.39 \\
\hline 10100 & Coal mining & 0.1297 & 1.00 & 1.00 \\
\hline 23100 & Petroleum refinery & 0.0114 & 1.01 & 1.00 \\
\hline 40100 & Electricity supply & 0.0215 & 4.18 & 0.53 \\
\hline 40200 & Gas supply & 0.0215 & 1.14 & 0.47 \\
\hline
\end{tabular}

a MSIC2000, The Malaysia Standard Industrial Classification 2000. 
Table 4

The direct and total emission intensity from Malaysia 2005 I-O table for cement using I-OLCA analysis from I-O product classification (IOPC) 26941.

\begin{tabular}{|c|c|c|c|c|c|c|c|c|}
\hline $\begin{array}{l}\text { Energy supply } \\
\text { sector }\end{array}$ & $\begin{array}{l}\text { Emission factor } \\
(\mathrm{kg} \\
\left.\mathrm{CO}_{2-e} / \mathrm{GJ}\right)^{\mathrm{a}, \mathrm{b}}\end{array}$ & $\begin{array}{l}\text { Average energy } \\
\text { tariffs, } T_{e} \\
(\mathrm{GJ} / \mathrm{RM} \$)\end{array}$ & $\begin{array}{l}\text { Disagg. } \\
\text { constant, } C_{d}\end{array}$ & $\begin{array}{l}\text { Primary energy } \\
\text { factors, PEF }\end{array}$ & $\begin{array}{l}\text { Total req. } \\
\text { coefficient, } T_{\mathrm{RC}} \\
\text { (RM\$/RM\$) }\end{array}$ & $\begin{array}{l}\text { Direct req. } \\
\text { coefficient, } D_{\mathrm{RC}} \\
\text { (RM\$/RM\$) }\end{array}$ & $\begin{array}{l}\text { Total emission } \\
\text { intensity, TEI } \\
\left(\mathrm{kg} \mathrm{CO} \text { CO }_{2} / \mathrm{RM} \$\right)\end{array}$ & $\begin{array}{l}\text { Direct emission } \\
\text { intensity, DEI } \\
\left(\mathrm{kg} \mathrm{CO}_{2-e} / \mathrm{RM} \$\right)\end{array}$ \\
\hline Crude oil & 69.16 & 0.0356 & 0.61 & 1.00 & 0.3064 & 0.0000 & 0.46312 & 0.00000 \\
\hline Natural gas & 51.33 & 0.0608 & 0.39 & 1.62 & 0.3064 & 0.0000 & 0.59737 & 0.00000 \\
\hline Coal mining & 88.25 & 0.1297 & 1.00 & 1.00 & 0.0040 & 0.0001 & 0.04619 & 0.00091 \\
\hline $\begin{array}{l}\text { Petroleum } \\
\text { refinery }\end{array}$ & 69.50 & 0.0114 & 1.00 & 1.01 & 0.5531 & 0.2991 & 0.44102 & 0.23848 \\
\hline $\begin{array}{l}\text { Electricity } \\
\text { supply }\end{array}$ & 244.66 & 0.0215 & 0.53 & 4.18 & 0.0578 & 0.0277 & 0.66826 & 0.32016 \\
\hline Gas supply & 51.33 & 0.0215 & 0.47 & 1.14 & 0.0578 & 0.0277 & 0.03458 & 0.01657 \\
\hline
\end{tabular}

a Relevant oxidation factors incorporated.

b Includes scope 1 assessment which measure $\mathrm{CO}_{2}, \mathrm{CH}_{4}$, and $\mathrm{N}_{2} \mathrm{O}$ from direct/point source emissions except electricity supply.

c Include scope 2 assessment which measure $\mathrm{CO}_{2}, \mathrm{CH}_{4}$, and $\mathrm{N}_{2} \mathrm{O}$ from indirect source emissions.

Table 5

Estimation of embodied emission intensity of basic materials inventories from Malaysia 2005 I-O table using HLCA.

\begin{tabular}{|c|c|c|c|c|}
\hline Description & Cement & Aggregate & Water & Reinforcement steel \\
\hline Total emission intensity, $\Sigma \mathrm{TCO}_{2-e} I\left(\mathrm{~kg} \mathrm{CO}_{2-e} / \mathrm{RM} \$\right)$ & 2.2505 & 0.9956 & 1.2763 & 1.4048 \\
\hline Direct emission intensity, $\Sigma \mathrm{DCO}_{2-e} I\left(\mathrm{~kg} \mathrm{CO}_{2-e} / \mathrm{RM} \$\right)$ & 0.5761 & 0.1708 & 0.5980 & 0.3645 \\
\hline Price, $\mathrm{RM} \$ / \mathrm{kg}(2005)$ & 0.1831 & 0.0186 & 0.0010 & 1.7797 \\
\hline Total emission intensity, $\mathrm{TCO}_{2-e} I\left(\mathrm{~kg} \mathrm{CO}_{2-e} / \mathrm{kg}\right)$ & 0.4120 & 0.0185 & 0.0013 & 2.5002 \\
\hline Direct emission intensity, $\mathrm{DCO}_{2-e} I\left(\mathrm{kgCO}_{2-e} / \mathrm{kg}\right)$ & 0.1055 & 0.0032 & 0.0006 & 0.6487 \\
\hline Indirect emission intensity $\left(\mathrm{kg} \mathrm{CO}_{2-e} / \mathrm{kg}\right)$ & 0.3066 & 0.0154 & 0.0007 & 1.8515 \\
\hline Direct emission intensity, $\mathrm{ECO}_{2-e} I_{D}\left(\mathrm{~kg} \mathrm{CO}_{2-e} / \mathrm{kg}\right)$ & 0.7400 & 0.0052 & 0.0017 & 2.8900 \\
\hline Total emission intensity, $\mathrm{ECO}_{2-e} I_{m}\left(\mathrm{~kg} \mathrm{CO}_{2-e} / \mathrm{kg}\right)$ & 1.0466 & 0.0206 & 0.0024 & 4.7415 \\
\hline
\end{tabular}

concrete wall panel production. For instance, the results of direct emissions intensity for cement is given in Tables 4 and 5 . The total primary direct emission intensity for each sector output of particular materials can then be calculated by summing all four primary energy intensities. The total primary direct emission intensity for sector output is given in Eq. (1) below.

$\mathrm{DCO}_{2-e} I=\sum_{e}^{E} D_{\mathrm{RC} e} \times T_{e} \times$ P.E.F $\mathrm{F}_{e} \times C_{e} \times I_{e}$

where $\mathrm{DCO}_{2-e} I$ is the direct emission intensity for a particular sector or product output $(\mathrm{GJ} / \mathrm{RM} \$) ; D_{\mathrm{RC}}$ is the direct requirement coefficient of energy sector $e(\mathrm{RM} \$ / \mathrm{RM} \$) ; E$ is the total number of energy supply sector, $e$ in I-O table; $T_{e}$ is average energy tariff $(\mathrm{GJ} / \mathrm{RM} \$) ;$ P.E.F $\mathrm{F}_{e}$ is the primary energy factor of energy supply sector $e$ (dimensionless); $C_{e}$ is the disaggregation constant for energy sub-sector, $e_{\text {.; }} I_{e}$ is the emission factor of energy supply sector, $e$.

Indirect emission intensity of material input is calculated by subtracting the direct emission intensity from the total emission intensity for a particular sector or product output. In this case, the total emission intensity from I-O table can be evaluated using Eq. (2) as shown below.

$\mathrm{TCO}_{2-e} I=\sum_{e}^{E} T_{\mathrm{RC} e} \times T_{e} \times$ P.E.F $F_{e} \times C_{e} \times I_{e}$

where $\mathrm{TCO}_{2-e} I$ is total emission intensity for a particular sector or product output $\left(\mathrm{kgCO}_{2-e} / \mathrm{RM} \$\right) ; T_{\mathrm{RCe}}$ is total requirement coefficient (Leontief inverse) of energy supply sector $e$ (RM\$/RM\$); $E$ is the total number of energy supply sector, $e$ in I-O table.

\subsection{Hybrid LCA for carbon emission intensity}

The HLCA combines the results obtained from PLCA and I-O LCA so that the completeness of system boundary in upstream materials production process can be increased. The indirect emission intensity of a particular materials sector can be identified by subtracting Eq. (2) from Eq. (1), respectively. The difference between total and direct emission intensity is then multiplied by material cost as shown in Table 6. In order to identify emission intensity for a material (cement, aggregate, water and reinforcement steel), the indirect emission intensity is combined with direct emission intensity using HLCA as given in Eq. (3) below.

$\mathrm{ECO}_{2-e} I_{m}=\mathrm{ECO}_{2-e} I_{D}+\left[\left(\mathrm{TCO}_{2-e} I-\mathrm{DCO}_{2-e} I\right) \times C_{m}\right]$

where $\mathrm{ECO}_{2-e} I_{m}$ is emission intensity of a materials; $\mathrm{ECO}_{2-e} I_{D}$ is direct emission intensity from process-based analysis; $C_{m}$ is the cost of material.

Besides basic materials, the assessments of carbon emissions embodied in concrete manufacturing are estimated by combining results of PLCA from basic material input (cement, aggregate, and water) based on the mix proportion of concrete. Different concrete mixtures posses different emission intensities. The carbon embodied in concrete is also influenced by sensitivity of price fluctuation over time. These variations have been demonstrated

Table 6

The estimation of direct and total emission intensity of concrete using hybrid analysis.

\begin{tabular}{|c|c|c|c|c|c|c|c|}
\hline Concrete Grade (MPa) & $\begin{array}{l}\text { Total emission } \\
\text { intensity, } \\
\mathrm{ECO}_{2-e} I_{\mathrm{mat}} \\
\left(\mathrm{kg} \mathrm{CO}_{2-e} / \mathrm{kg}\right)\end{array}$ & $\begin{array}{l}\text { Direct emission } \\
\text { intensity, } \\
\mathrm{DCO}_{2-e} I_{\text {con }} \\
\left(\mathrm{kg} \mathrm{CO}_{2-e} / \mathrm{RM} \$\right)\end{array}$ & Price $\left(\mathrm{RM} \$ / \mathrm{m}^{3}\right)$ & $\begin{array}{l}\text { Concrete } \\
\text { density, } \rho \\
\left(\mathrm{kg} / \mathrm{m}^{3}\right)\end{array}$ & Price $(\mathrm{RM} \$ / \mathrm{kg})$ & $\begin{array}{l}\text { Direct emission } \\
\text { intensity, } \\
\mathrm{DCO}_{2-e} I_{\text {con }} \\
\left(\mathrm{kg} \mathrm{CO}_{2-e} / \mathrm{kg}\right)\end{array}$ & $\begin{array}{l}\text { Embodied } \\
\text { emission } \\
\text { intensity, } \\
\mathrm{ECO}_{2-e} I_{\text {con }}(\mathrm{kg} \\
\left.\mathrm{CO}_{2-e} / \mathrm{kg}\right)\end{array}$ \\
\hline 25 & 0.155 & 0.265 & 145.04 & 2566.60 & 0.057 & 0.015 & 0.170 \\
\hline 30 & 0.182 & 0.265 & 153.29 & 2536.00 & 0.060 & 0.016 & 0.198 \\
\hline 40 & 0.201 & 0.265 & 172.82 & 2390.40 & 0.072 & 0.019 & 0.220 \\
\hline
\end{tabular}


using sensitivity analysis as shown in Section 5. The emissions intensity for concrete is derived from Eqs. (3) and (1), with detailed material inputs given in Eq. (5) below.

$$
\begin{aligned}
& \mathrm{ECO}_{2-e, T}=\sum_{m=1}^{M}\left(\mathrm{ECO}_{2-e} I_{m} \times W \times Q_{m}\right)+\frac{\mathrm{DCO}_{2-e} I_{n}}{\rho_{\text {con }}} \times C_{\mathrm{pdt}} \\
& \mathrm{ECO}_{2-e, T}=\left(\mathrm{ECO}_{2-e} I_{\mathrm{cem}} \times Q_{\mathrm{cem}}+\mathrm{ECO}_{2-e} I_{\mathrm{agg}} \times Q_{\mathrm{agg}}+\mathrm{ECO}_{2-e} I_{\mathrm{wtr}}\right. \\
& \left.\times Q_{\mathrm{wtr}}\right) \times(1+W)+\frac{\mathrm{DCO}_{2-e} l_{n}}{\rho_{\text {con }}} \times C_{\text {con }}
\end{aligned}
$$

where $\mathrm{ECO}_{2-e, T}$ is total emission using hybrid LCA; $Q_{m}$ is quantity of material input to product; $C_{\text {pdt }}$ is cost of product; $Q_{c e m}, Q_{a g g}, Q_{w t r}$ is quantity of cement, aggregate (course and fine aggregate) and water respectively; $\mathrm{ECO}_{2-e} I_{\mathrm{cem}}, \mathrm{ECO}_{2-e} I_{\mathrm{agg}}, \mathrm{ECO}_{2-e} I_{\mathrm{wtr}}$ is carbon emission intensity of cement, aggregate and water respectively; $W$ is waste percentage; $C_{\text {con }}$ is cost of concrete.

The mix proportion of concrete is dependent on the required concrete strength. Different mixtures have different carbon emission intensity. For instance, the $30 \mathrm{MPa}$ grade concrete with mix proportion of $15 \%, 79 \%$, and $6 \%$ of cement, aggregate and water have carbon emissions of $0.157 \mathrm{~kg} \mathrm{CO} C_{-e} / \mathrm{kg}, 0.016 \mathrm{~kg} \mathrm{CO}_{2-e} / \mathrm{kg}$, and $0.0001 \mathrm{~kg} \mathrm{CO}_{2-e} / \mathrm{kg}$, respectively. This mix proportion produces $0.198 \mathrm{~kg} \mathrm{CO} 2_{-e} / \mathrm{kg}$ of carbon emission for $30 \mathrm{MPa}$ concrete using HLCA from Eq. (5). The wastage is assumed to be $5 \%$ for both concrete and steel reinforcement. The detailed emission assessment of different concrete grades is given in Table 6.

\subsection{Carbon emission comparison in a conventional concrete construction system versus an IBS building system incorporating precast concrete wall panel}

The layout plan of the 2-storey residential building and application of IBS components is given in Figs. 4 and 5. A model was developed to obtain the optimum production line set up with a limited number of wall panels. The developed model has a floor area size of $16.5 \mathrm{~m}$ length $\times 9.6 \mathrm{~m}$ width, with the height of both stories at $3.0 \mathrm{~m}$. The wall and slab thickness was assumed to be $100 \mathrm{~mm}$ and $125 \mathrm{~mm}$, respectively.

The building was designed using conventional methodology in accordance with the British Standard (BS 8110, 1985). The conventional system considered the load distribution to the main structural frame of the building (slab, beam, column, and foundation). The non-load bearing walls (clay bricks) were only employed as external and internal partitioning i.e. these were non-load bearing elements.

The IBS building system using precast wall panels were employed as a comparison to identify carbon emission in each of IBS components. To achieve feasibility of IBS system, the aspect of standardization was incorporated in designing the system. The standardization includes the use of standard wall sizes in order to reduce the cost of manufacturing. Instead of using the typical cast-in situ construction method, precast wall panels are used in the IBS precast method. All the proposed walls have fixed heights $(3000 \mathrm{~mm})$ and thickness $(100 \mathrm{~mm})$ in accordance with the typical 2 -storey residential building designed (Fig. 5). The range of coordinating sizes for slab and wall panels and door and window opening were used according to the IBS Modular Design Guide (2000). The different types of precast wall panels are illustrated in Fig. 6.

\section{Results and discussion}

Embodied carbon intensity derived using HLCA, as previously discussed, was applied to the case study of a 2-storey residential building comparing different building systems. The total carbon

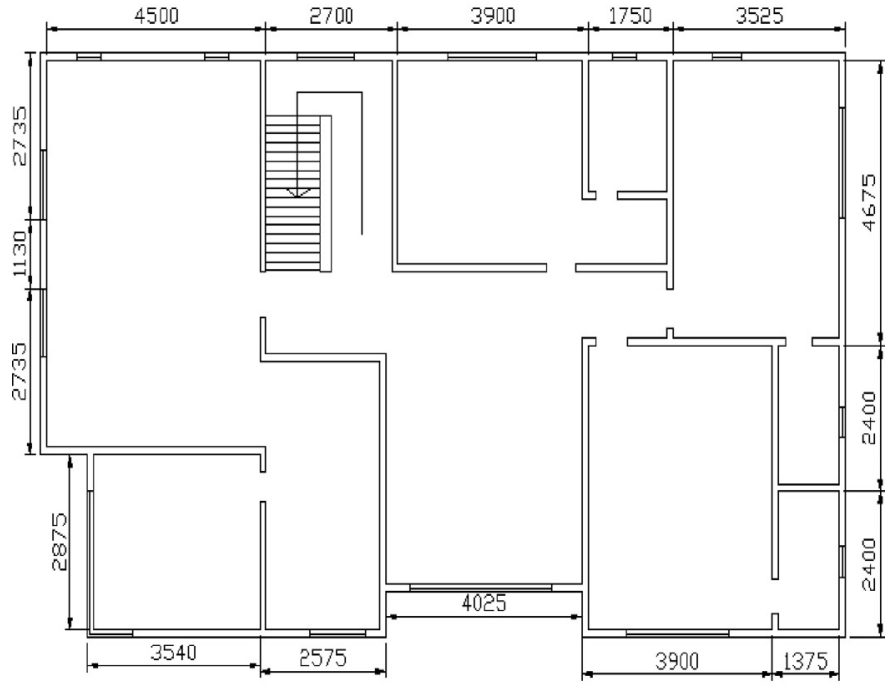

(a)

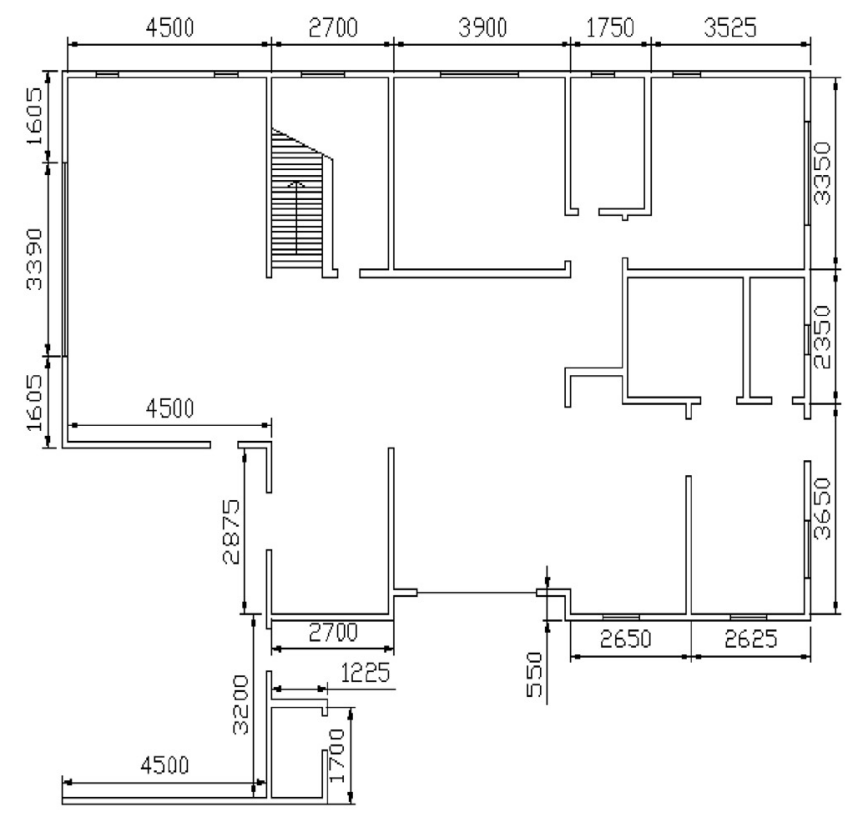

(b)

Fig. 4. Plan of the conventional building system. (a) Ground floor, (b) first floor (all units in $\mathrm{mm}$ ).

dioxide equivalents of the building systems investigated are presented in Table 8 for material comparison requirements. The influence of indirect and direct carbon in materials and component productions are demonstrated in Figs. 7 and 8, respectively.

The comparison of material quantities between the conventional and IBS building systems are given in Table 7. Both design options utilize uniform concrete strength and only consider load bearing elements to ensure accurate comparison. Therefore, the infill materials, namely non-load bearing bricks forming the walls in the conventional system were excluded from the analysis. The results of the HLCA for both cases are given in Fig. 8. The total emissions of the 2-storey residential building were estimated by multiplying the calculated total carbon emission per floor by the number of stories. The results show emissions of $128.36 t \mathrm{CO}_{2-e}$ for 
Table 7

Comparison of material quantity between conventional and IBS design using precast concrete wall panel.

\begin{tabular}{|c|c|c|c|c|}
\hline \multirow[t]{2}{*}{ Components } & \multicolumn{2}{|l|}{ Conventional design } & \multicolumn{2}{|l|}{ IBS design } \\
\hline & Quantity of concrete $\left(\mathrm{m}^{3}\right)$ & Quantity of steel (kg) & Quantity of concrete $\left(\mathrm{m}^{3}\right)$ & Quantity of steel $(\mathrm{kg})$ \\
\hline Beam & 12.7 & 2808 & - & - \\
\hline Column & 3.3 & 1847 & - & - \\
\hline Slab & 19.5 & 5038 & 14.62 & 4577 \\
\hline Wall & - & - & 25.67 & 902 \\
\hline Total & 35.5 & 9693 & 40.29 & 5479 \\
\hline
\end{tabular}

conventional cast in situ concrete system and $94.64 t \mathrm{CO}_{2-e}$ for the IBS building system. Of that, $33.72 t \mathrm{CO}_{2-\mathrm{e}}$ emissions are prevented accounting for a $26.27 \%$ reduction in total emissions achieved through the utilization of an alternative construction method.

As shown in Table 8, material and component production significantly contributed to the overall buildings emissions accounting for more than $90 \%$. Therefore the total carbon emissions can be further reduced through the precast concrete production phase. Steel reinforcement and concrete materials significantly contributed to carbon emissions for both conventional and IBS system. Similar findings were reported by previous researchers (Goggins et al., 2010; Guggemos \& Horvath, 2005). Embodied carbon in steel reinforcement and concrete materials account for $71.61 \%$ and $27.27 \%$ respectively for the conventional system. In IBS system, embodied carbon in steel reinforcement and concrete material were $54.90 \%$ and $42.72 \%$, respectively. The lower embodied carbon in steel reinforcement is particularly notable because of advantages using the IBS system enabling a reduction in steel usage due to the manufacturing and quality control processes. However, for concrete materials, embodied carbon in the IBS system is higher than the conventional system particularly in wall components. The main reason for the higher value is the load bearing nature of the wall elements in this structure. The carbon emissions associated with plant operation and transportation was found to be less significant for both systems. The carbon emissions for transportation of steel reinforcement, concrete and precast components was less than $1 \%$. Local transportation like that considered for this analysis yield these results, however, it should be noted that increases in transportation distances should be appropriately considered. The carbon emission due to precast concrete production was less significant contributing only $1.61 \%$ of total carbon emission. The carbon emission from the concrete batching plant for the conventional system was included in I-O LCA and not presented in this analysis.

As illustrated in Fig. 7, steel reinforcement contributed the largest component of embodied carbon for both systems. Considering indirect embodied carbon using HLCA has increased the boundary completeness by up to $45 \%$ compared to PLCA. The scale of I-O LCA to the PLCA results for the material productions for the conventional system was $39.05 \%$ for reinforcement steel and $30.81 \%$ for slabs, columns, and beams respectively. For IBS system, the I-O LCA was able to estimate indirect values for the steel reinforcement, walls and slabs as $39.05 \%$ and $30.81 \%$, respectively. Overall, these results indicate that HLCA was better at estimating the embodied carbon by increasing system boundary completeness including upstream material production processes. It can be seen that the underestimation of embodied carbon for reinforcement steel and concrete by the I-O LCA and PLCA are due to raw energy intensity materials used (cement, basic iron and steel) for further processing. Analysing these results, we identified that the indirect contribution from cement was $29 \%$ for both methods, which indicates that part of the emissions originated from upstream processes. This can be explained by the relatively high contribution of indirect carbon emissions from energy supply to selected products in the I-O product classification. For instance, we identified that direct emission intensities $\left(0.0052 \mathrm{~kg} \mathrm{CO}_{2-e} / \mathrm{kg}\right)$ are smaller than indirect emissions $\left(0.0154 \mathrm{~kg} \mathrm{CO}_{2-e} / \mathrm{kg}\right)$ for aggregate supply to concrete production shown in Table 5 . This inaccuracy was compensated by using the HLCA. Using processbased LCI data to quantify direct emission while maintaining the comprehensiveness of system boundary via I-O LCA can improve estimation of embodied carbon for material production.

\subsection{Sensitivity analysis of results}

Input-output tables of Malaysian economic structure are publicly published every 5 years with 2005 I-O tables are the latest tables produced by Malaysian Department of Statistic. However, product prices used to convert economic data into physical data in I-O LCA change continuously. Technological coefficient in I-O tables are considered stable for mature technologies such as concrete production, the raw materials used in their production (e.g. cement) might be subjected to significant variation over time. Variability in prices is especially relevant for concrete and steel reinforcement that are linked to the energy intensity commodities such as cement and steel reinforcement.

The impacts of price variability from period of 2005-2011 on I-O LCA and HLCA are presented in Table 9. The coefficient of variance (COV) analysis is conducted before and after hybridization of LCA to measure the sensitivity of price towards the hybrid method. Analysing these show price fluctuation in raw materials (cement

Table 8

Carbon emission for precast wall panel system and conventional system per floor.

\begin{tabular}{|c|c|c|c|c|}
\hline \multirow[t]{2}{*}{ Material components } & \multicolumn{2}{|c|}{ Conventional system } & \multicolumn{2}{|l|}{ IBS system } \\
\hline & $\mathrm{kgCO} 2-e$ & Percent & $\mathrm{kgCO} 2-e$ & Percent \\
\hline Beam & 6371.58 & 9.93 & - & - \\
\hline Column & 1655.61 & 2.58 & - & - \\
\hline Slab & 9783.13 & 15.24 & 7334.84 & 15.50 \\
\hline Wall & - & - & $12,878.61$ & 27.21 \\
\hline Reinforcement steel & $45,959.42$ & 71.61 & $25,978.71$ & 54.90 \\
\hline Transportation (concrete) & 244.78 & 0.38 & - & - \\
\hline Transportation (reinforced steel) & 163.70 & 0.26 & 92.53 & 0.20 \\
\hline Precast concrete plant operation & - & - & 759.69 & 1.61 \\
\hline Transportation (precast components) & - & - & 277.80 & 0.59 \\
\hline Total & & & & \\
\hline
\end{tabular}




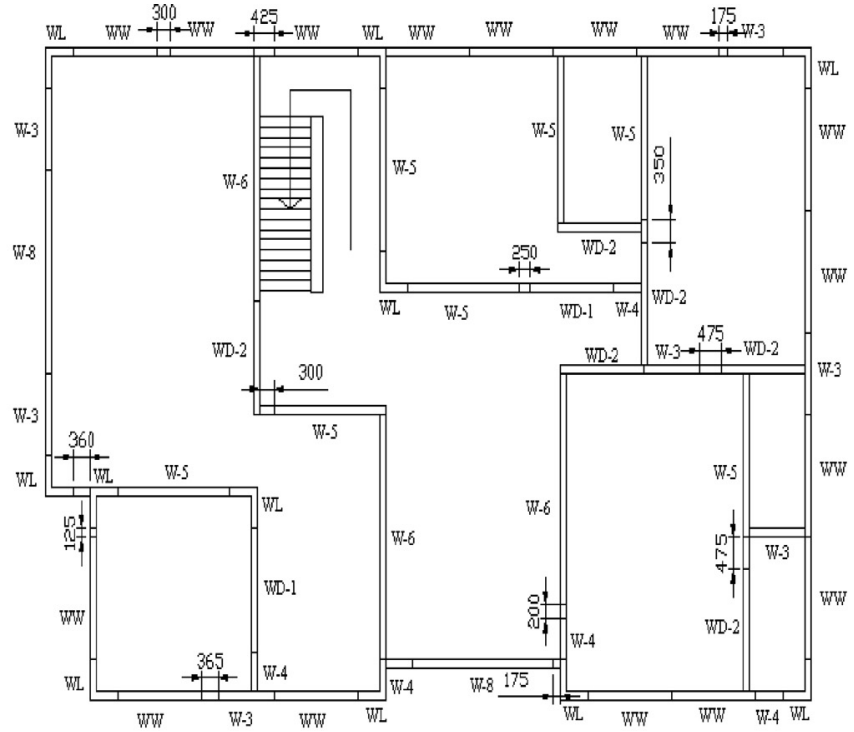

(a)

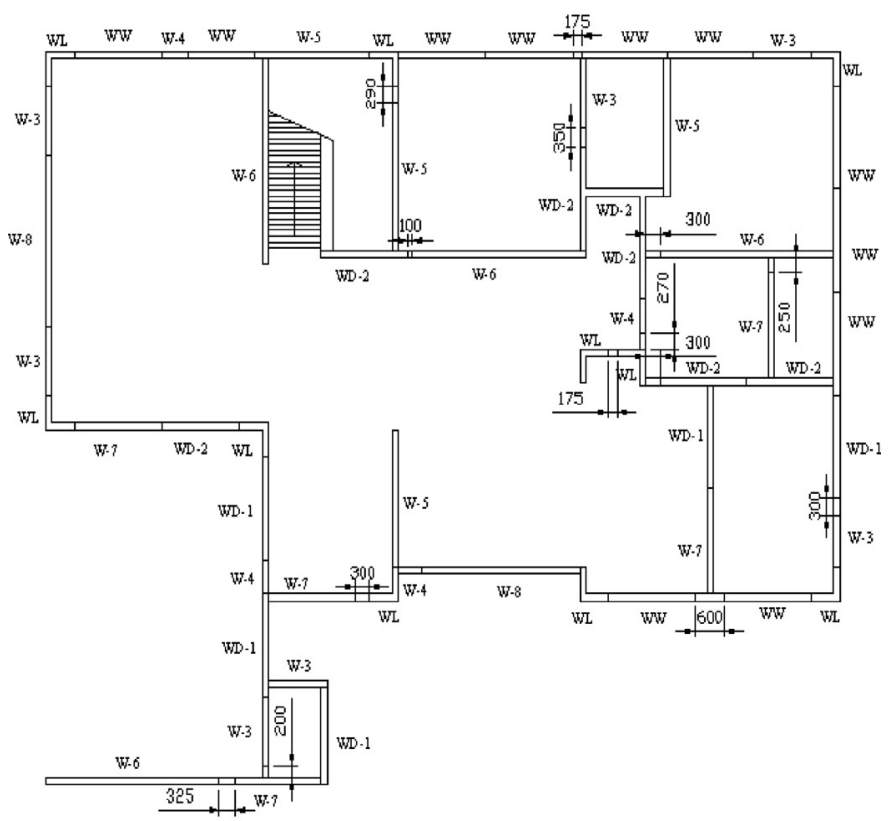

(b)

Fig. 5. Plan of the IBS Building. (a) Ground floor, (b) first floor (all units in mm).

Table 9

Variability of embodied carbon intensity $\left(\mathrm{kg} \mathrm{CO}_{2-\mathrm{e}} / \mathrm{kg}\right)$ in HLCA due to the changes in raw materials prices (2005-2011).

\begin{tabular}{llllllll}
\hline \multirow{2}{*}{ Year } & \multicolumn{2}{l}{ Cement } & & & & \multicolumn{2}{l}{ Reinforcement steel } \\
\cline { 2 - 3 } \cline { 6 - 7 } & Total $_{\text {IOLCA }}$ & Direct $_{\text {IOLCA }}$ & Total $_{\text {HLCA }}$ & & Total $_{\text {IOLCA }}$ & Direct $_{\text {IOLCA }}$ & Total $_{\text {HLCA }}$ \\
\hline 2005 & 0.4120 & 0.1055 & 1.0466 & & 2.5002 & 0.6487 & 4.7415 \\
2006 & 0.4597 & 0.1177 & 1.0820 & & 2.7038 & 0.7015 & 4.8923 \\
2007 & 0.5019 & 0.1285 & 1.1134 & & 2.8969 & 0.7516 & 5.0353 \\
2008 & 0.5007 & 0.1282 & 1.1126 & & 4.5265 & 1.1745 & 6.2421 \\
2009 & 0.6189 & 0.1584 & 1.2005 & & 2.9470 & 0.7647 & 5.0724 \\
2010 & 0.6470 & 0.1656 & 1.2214 & & 3.2069 & 0.8321 & 5.2649 \\
2011 & 0.6883 & 0.1762 & 1.2521 & & 3.5862 & 0.9305 & 5.5457 \\
COV & 0.191 & 0.191 & 0.068 & & 0.214 & 0.214 & 0.096 \\
\hline
\end{tabular}
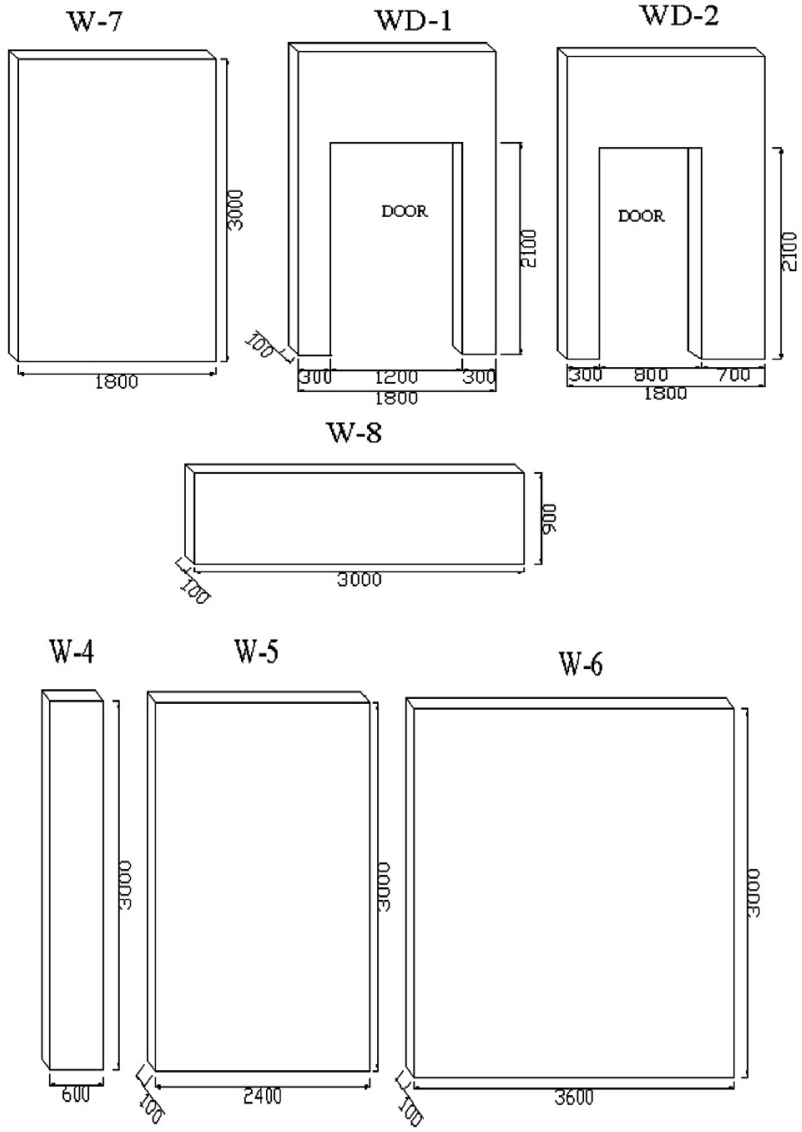

WL

WW

W-3
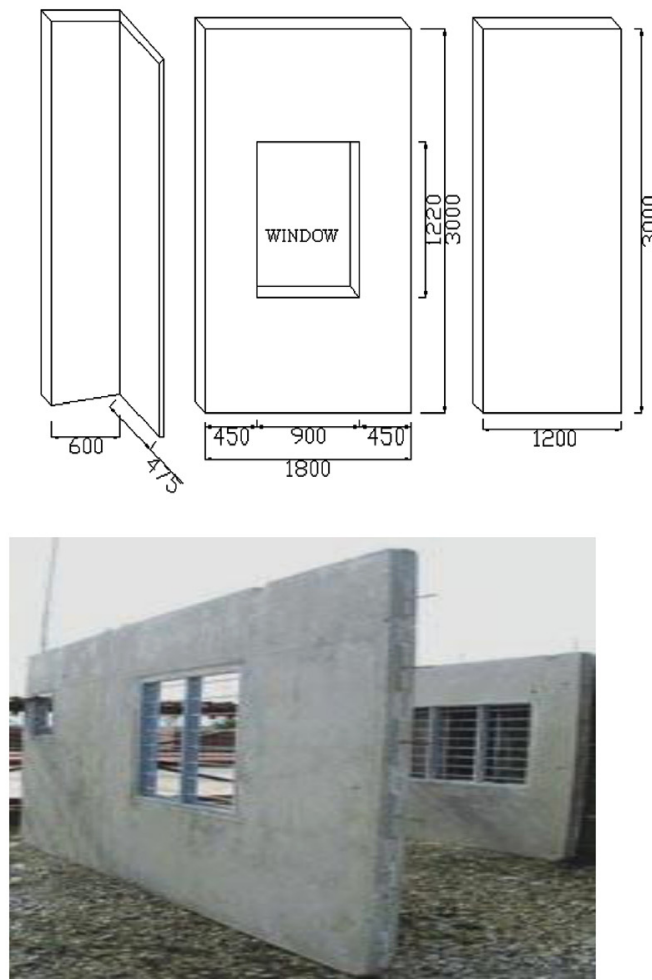

Fig. 6. Different type of wall for the IBS building system (all unit in $\mathrm{mm}$ ) (IBS Modular Design Guide, 2000). 


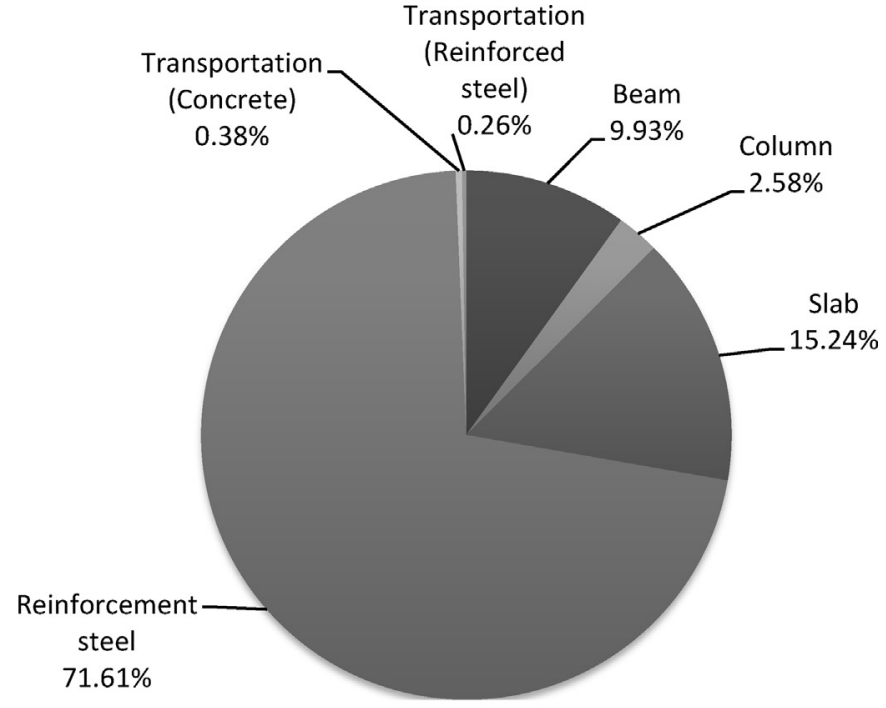

(a)

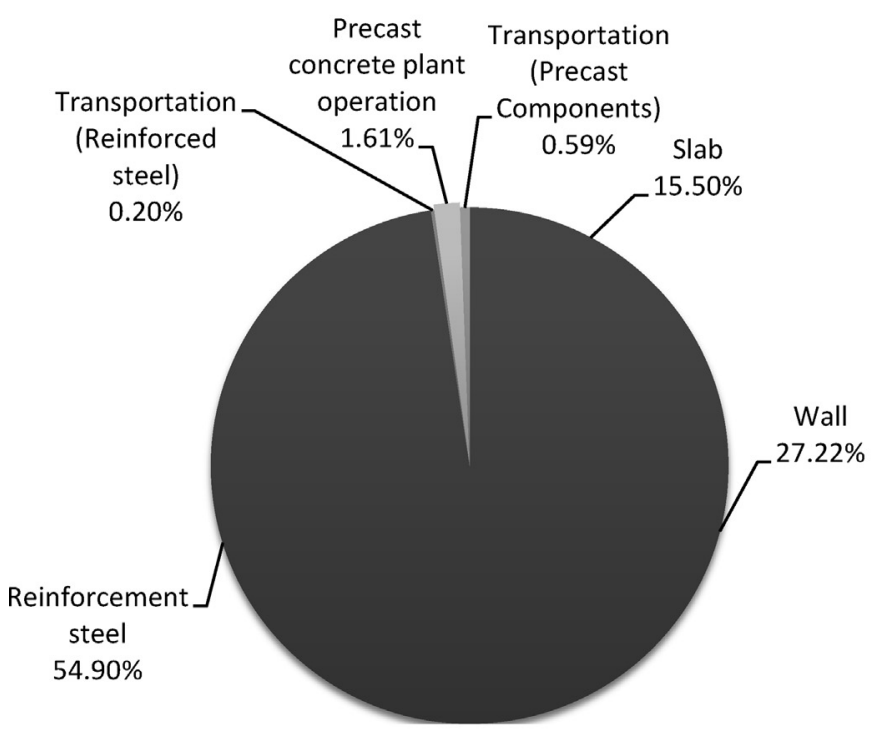

(b)

Fig. 7. Distribution of carbon emission in building system. (a) Conventional system, (b) precast wall panel system.

for concrete) can lead to variation in I-O LCA by as much as $19.1 \%$. In the case of energy intensive materials like steel reinforcement, variation in I-O LCA can increase by up to $21.4 \%$. However, the HLCA shows less sensitivity to commodity price fluctuation than I-O LCA comparatively varying between $6.8 \%$ and $9.6 \%$. The interface between process and I-O LCA has a vital role in the robustness of hybrid method to commodity price variation. Most supply chains for material inputs in product manufacturing are covered by PLCA where indirect emission is smaller than direct emission from PLCA. If the direct emissions are much smaller than indirect emissions, the HLCA results might become more sensitive to price variability.

\subsection{Comparison with car emission and building production}

The Malaysian government is in the process of adopting more clean technology to improve the future of the countries environmental performance. In context, the application of the results of this
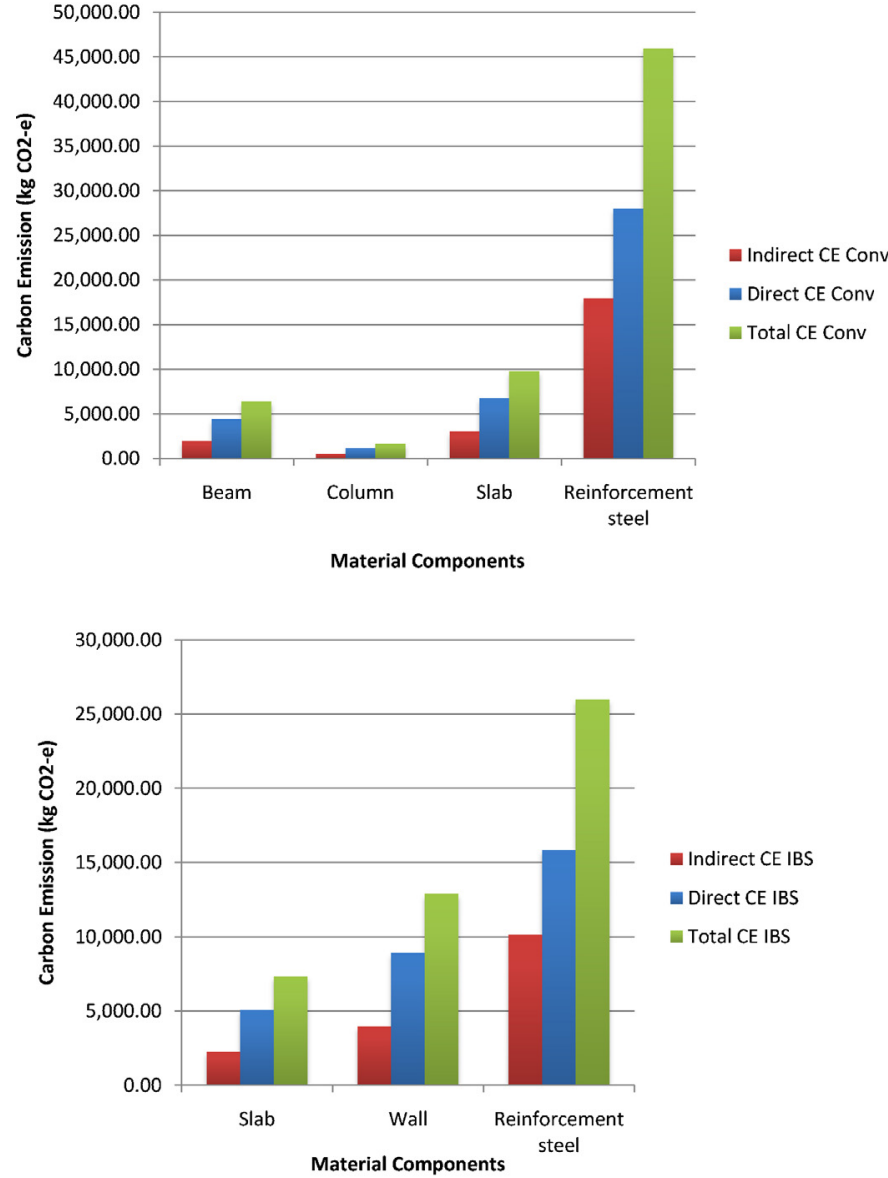

Fig. 8. Detail direct and indirect CE for material inputs in (a) conventional system and (b) precast wall panel system.

study has the potential to significantly impact this. We intend to contextualize the carbon emission saving by using precast concrete wall panels by comparing two sets of more commonly recognized results; (1) carbon emission produced by average annual car usage, and (2) the average annual building production.

The equivalent savings achieved from the application of IBS components can be seen through the average annual car usage and average annual building production. The average car emissions according to the fuel combustion emission factor released by Department of Climate Change and Energy Efficiency (2011) is $2.331 \mathrm{~kg} \mathrm{CO}$ CO-e $_{2} / \mathrm{L}$ and assumed average fuel consumption of $14.5 \mathrm{~km} / \mathrm{L}$ and $14,000 \mathrm{~km} /$ year for an average passenger car. Accordingly, this car will emit on average: $2.331 \times 14,000 /(14.5 \times 1000)=2.251 t \mathrm{CO}_{2-e} /$ year to the atmosphere. Having said that, an equivalent of 33.72/2.251 =14.98 cars can be saved annually per 2 storey structure, constructed using the more efficient IBS system. In other context, the population of Malaysia is $29,406,077$ at increasing rate of $2.17 \%$ that is 638,112 person per year (Department of Statistics, 2012a). The Malaysia average occupancy rate is 4.31 person per dwelling (Department of Statistics, 2012b). Assume the increased population presented were all accommodated in a 2-storey residential house using the IBS building system, the net result would be: $638,112 / 4.31=140,054$ new dwellings/year. Therefore, using the IBS building system would reduce embodied carbon by $638,112 \times 33.72=4.72$ million $t \mathrm{CO}_{2-e}$ per year.

Similarly, with respect to the car, the net result of the simple selection of the IBS building system over a less would result in the following annual reduction of car traffic from Malaysian roads 
adding to further environmental benefits would be: 140,054 new dwellings/year $\times 14.98$ cars $=2,098,008.92$ car emissions saved annually. These outcomes would result in a significant contribution towards the Malaysian government's goal of achieving a $40 \%$ reduction in GHG emissions by 2020.

\section{Conclusion}

This paper assesses the carbon emissions of two construction approaches for a typical 2-storey residential structure in Malaysia using a HLCA approach. This considers both direct and indirect emissions by expanding the system boundary from cradle to site of LCA. Instead of quantifying direct emissions only, this research highlighted the significant amount of indirect emissions that are associated particularly with steel reinforcement and concrete. These materials make up the complete material requirements of the structural systems analyzed. Given the energy intensive requirements of these materials the indirect emissions should always be considered when assessing the environmental impact of a structure. Moreover, price fluctuation in the raw materials used for the construction production can be reduced by using HLCA which provides more robust outputs.

The assessment revealed that a total emissions reduction of $26.27 \%$ is achievable through the selection of a precast wall panel system in the given structure. An equivalent saving of 4.72 million $t \mathrm{CO}_{2-e}$ can be achieved annually if the entire Malaysia construction industry adopted the IBS construction system. The study identified that $90 \%$ of emissions associated with these construction methods originated from the material production. This result highlights potential future scope for further improvements through a concerted industry effort on the reduction of material manufacturing emissions. Moreover, significant carbon emission reductions can be achieved by the widespread adoption of the IBS system due to the increasing demand in the Malaysian construction industry. This is particularly applicable for the public project and will subsequently contribute to national carbon emission reductions. This research highlighted the potential significant contribution of improved efficiencies available through the IBS building system in Malaysia using precast wall panels. Until recently, there was no such comprehensive LCI database in Malaysia to provide a platform for carbon emission assessment, particularly in the construction industry. This research serves as a starting point for promoting sustainable development through carbon emission reductions in Malaysia.

\section{References}

Abdul Kadir, M. R., Lee, W. P., Jaafar, M. S., Sapuan, S. M., \& Ali, A. A. A. (2006). Construction performance comparison between conventional and industrialised building systems in Malaysia. Structural Survey, 24(5), 412-424.

Acquaye, A. A. (2010). A stochastic hybrid embodied energy and $\mathrm{CO}_{2-e q}$ intensity analysis of building and construction processes in Ireland. Ireland, Dublin: Dublin Institute of Technology (DIT) (PhD doctoral thesis).

Acquaye, A. A., \& Duffy, A. P. (2010). Input-output analysis of Irish construction sector greenhouse gas emissions. Building and Environment, 45(3), 784-791.

Acquaye, A. A., Duffy, A. P., \& Basu, B. (2011). Stochastic hybrid embodied $\mathrm{CO}_{2}$ eq analysis: An application to the Irish apartment building sector. Energy and Buildings, 43(6), 1295-1303.

Alcorn, J. A., \& Baird, G. (1996). Use of a hybrid energy analysis method for evaluating the embodied energy of building materials. Renewable Energy, 8(1-4), 319-322.

Aye, L., Ngo, T., Crawford, R. H., Gammampila, R., \& Mendis, P. (2012). Life cycle greenhouse gas emissions and energy analysis of prefabricated reusable building modules. Energy and Buildings, 47(0), 159-168.

Bullard, C. W., Penner, P. S., \& Pilati, D. A. (1978). Net energy analysis: Handbook for combining process and input-output analysis. Resources and Energy, 1(3), $267-313$.
Crawford, R. H. (2008). Validation of a hybrid life-cycle inventory analysis method. Journal of Environmental Management, 88(3), 496-506.

Crawford, R. H., Czerniakowski, I., \& Fuller, R. J. (2010). A comprehensive framework for assessing the life-cycle energy of building construction assemblies (Report). Architectural Science Review, 53(3), 288 (289).

Department of Climate Change and Energy Efficiency. (2011). National greenhouse account factors. Australia: Department of Climate Change and Energy Efficiency.

Department of Statistics. (2010). Input-output tables Malaysia 2005. Malaysia: Department of Statistics.

Department of Statistics. (2012a). Table 1: Distribution of population (number $\mathcal{E}$ percentage) and average annual population growth rate by state (1980-2010). Malaysia: Department of Statistics.

Department of Statistics. (2012b). Table 3: Average household size by state (1980-2010). Malaysia: Department of Statistics.

Dixit, M. K., Fernández-Solís, J. L., Lavy, S., \& Culp, C. H. (2010). Identification of parameters for embodied energy measurement: A literature review. Energy and Buildings, 42(8), 1238-1247.

Dixit, M. K., Fernández-Solís, J. L., Lavy, S., \& Culp, C. H. (2012). Need for an embodied energy measurement protocol for buildings: A review paper. Renewable and Sustainable Energy Reviews, 16(6), 3730-3743.

Finnveden, G., Hauschild, M.Z., Ekvall, T., Guinée, J., Heijungs, R., Hellweg, S., Koehler, A., Pennington, D., \& Suh, S. (2009). Recent developments in life cycle assessment. Journal of Environmental Management, 91(1), 1-21.

Goggins, J., Keane, T., \& Kelly, A. (2010). The assessment of embodied energy in typical reinforced concrete building structures in Ireland. Energy and Buildings, 42(5), 735-744.

Guggemos, A. A., \& Horvath, A. (2005). Comparison of environmental effects of steel- and concrete-framed buildings. Journal of Infrastructure Systems, 11(2), 93-101.

Hammond, G. P., \& Jones, C. I. (2011). Inventory of (embodied) carbon \&' energy (ICE) Ver 2.0. UK: University of Bath.

IBS Modular Design Guide. (2000). Implementation of modular co-ordination in building in Malaysia. Modular Working Group Research Division, Ministry of Housing and Local Government.

International Energy Agency. (2005). Malaysia energy balance 2005. France: International Energy Agency (IEA).

ISO 14040. (2006). Environmental management - Life cycle assessment - Principles and framework. Switzerland: International Standard Organization (ISO).

Lenzen, M., Murray, S. A., Korte, B., \& Dey, C. J. (2003). Environmental impact assessment including indirect effects - A case study using input-output analysis. Environmental Impact Assessment Review, 23(3), 263-282.

Lenzen, M., \& Treloar, G. (2002). Embodied energy in buildings: Wood versus concrete - Reply to Börjesson and Gustavsson. Energy Policy, 30(3), 249-255.

Malaysia Energy Centre. (2008). Study on grid connected electricity baselines in Malaysia. Malaysia: Malaysia Energy Centre.

Malaysia Energy Commission. (2005). Malaysia energy information hub. Putrajaya, Malaysia: Malaysia Energy Commission, Ministry of Energy, Green Technology and Water.

Malaysia Energy Commission. (2009). National energy balace 2009. Putrajaya, Malaysia.

Marceau, M. L., Nisbet, M. A., \& VanGeem, M. G. (2007). Life cycle inventory of portland cement concrete. Skokie, IL, USA: Portland Cement Association.

Mattila, T. J., Pakarinen, S., \& Sokka, L. (2010). Quantifying the total environmental impacts of an industrial symbiosis - A comparison of process-hybrid and input-output life cycle assessment. Environmental Science E'Technology, 44(11), 4309-4314

Monahan, J., \& Powell, J. C. (2011). An embodied carbon and energy analysis of modern methods of construction in housing: A case study using a lifecycle assessment framework. Energy and Buildings, 43(1), 179-188.

Mongelli, I., Suh, S., \& Huppes, G. (2005). A structure comparison of two approaches to LCA inventory data, based on the MIET and ETH databases. The International Journal of Life Cycle Assessment, 10(5), 317-324.

Nässén, J., Holmberg, J., Wadeskog, A., \& Nyman, M. (2007). Direct and indirect energy use and carbon emissions in the production phase of buildings: An input-output analysis. Energy, 32(9), 1593-1602.

PAS 2050. (2011). The guide to PAS 2050:2011 - How to carbon footprint your products, identify hotspots and reduce emissions in your supply chain. London, UK: British Standard Institution (BSI).

Peng, W., \& Pheng, L. S. (2011). Managing the embodied carbon of precast concrete columns. Journal of Materials in Civil Engineering, 23(8), 1192-1199.

Treloar, G. J. (1997). Extracting embodied energy paths from input-output tables: Towards an input-output-based hybrid energy analysis method. Economic Systems Research, 9(4), 375, 375.

Treloar, G. J., Love, P. E. D., \& Faniran, O. O. (2001). Improving the reliability of embodied energy methods for project life-cycle decision making. Journal of Enterprise Information Management, 14(5/6), 303-317.

Williams, E. D., Weber, C. L., \& Hawkins, T. R. (2009). Hybrid framework for managing uncertainty in life cycle inventories. Journal of Industrial Ecology, 13(6), 928-944. 